\title{
Genetic diversity of blue swimming crab (Portunus pelagicus Linn 1758) from Indonesian waters (Sunda and Sahul Shelf, Wallacea region): Phylogenetic approach
}

\author{
ANDI ALIAH HIDAYANI ${ }^{1}$, YUSHINTA FUJAYA ${ }^{1, \boldsymbol{}}$, DODY DH.TRIJUNO ${ }^{1}$, NITA RUKMINASARI ${ }^{1}$, \\ ALIMUDDIN ALIMUDDIN ${ }^{2}$ \\ ${ }^{1}$ Department of Fisheries, Faculty of Marine Science and Fisheries. Universitas Hasanuddin. Jl. Perintis Kemerdekaan Km. 10, Makassar, South \\ Sulawesi, Indonesia. Tel./fax.: +62-411-586025. ”email: yushinta.fmuskar@gmail.com, aliah@ fikp.unhas.ac.id \\ ${ }^{2}$ Department of Aquaculture, Faculty of Fisheries and Marine Science, Institut Pertanian Bogor. Dramaga, Bogor 16680, West Java, Indonesia
}

Manuscript received: 17 February 2020. Revision accepted: 20 April 2020.

\begin{abstract}
Hidayani AA, Fujaya Y, Trijuno DD, Rukminasari N, Alimuddin A. 2020. Genetic diversity of blue swimming crab (Portunus pelagicus Linnaeus 1758) from Indonesian waters (Sunda and Sahul Shelf, Wallacea region): Phylogenetic approach. Biodiversitas 21: 2097-2102. Blue swimming crab is one of the exploited fisheries commodities in Indonesia. This condition has contributed to the decline of their genetic diversity. The information on genetic diversity assumes importance for the conservation and the cultural purposes of species. The study aimed to determine the genetic diversity of blue swimming crabs from Indonesian waters using phylogenetic analysis. We conducted sampling of crab from several Indonesian waters, such the Aceh and Semarang (representing Sunda Shelf), Barru, South Sulawesi, and Maumere, Flores (representing Wallacea region) and Sorong, Raja Ampat and Kaimana (representing Sahul Shelf). Genetic diversity in this study using mitochondrial DNA (mtDNA) by implementing the method of Cytochrome c Oxidase Subunit I (COI). According to the findings, the blue swimming crabs from our study sites had a high genetic diversity variation. Three groups of crabs were determined using phylogenetic tree which formed three different unique clades. There was the same haplotype of crab observed from different locations, barring a sample from the Sahul Shelf which has a unique haplotype. There was no genetic speciation of crab samples from the Sunda Shelf and the Wallacea region were observed, except samples from the Sahul Shelf. Hybridization might occur between species of the crabs due to the finding of a cryptic species.
\end{abstract}

Keywords: Indonesian water, COI, phylogenetic approach, Portunus pelagicus

\section{INTRODUCTION}

Blue Swimming Crab (Portunus pelagicus) is one of the most critical fishery-based commodities in the world. This crab was distributed at Indo Pacific, Japan, and the Philippines through South East and East Asia to Australia, Fiji, Red Sea, and East Africa (FAO Fisheries and Aquaculture Department 2014). The majority of swimming crab producer countries have reported that this community has been over-exploitation which was threatening the sustainability of this crab (Svane and Hooper 2004; Sawusdee and Songrak 2009; Kamrani et al. 2010; Mehanna et al. 2013 and Kunsook et al. 2014).

Over-exploitation of the organism will be caused a decline in genetic diversity, consequently leading to the decline of heterogeneity (Garcia de Leaniz et al. 2007). In the wild, inbreeding between species has resulted in inferior genetic quality as a consequence of the decline in the reproduction performance, particularly the number of larvae and survival rates (Sawitri and Takadjandji 2014). Hybridization among species with a far genetic distance is a technique that could help resolve the problem relating to decreasing genetic quality. For crab culture, it is crucial to provide detailed on crab genetic information from Indonesian waters. In this study, we conducted a molecular-based identification of blue swimming crab $(P$. pelagicus) from several Indonesian waters, which representing three regions of Indonesia (Sunda Shelf, Wallacea region, and Sahul shelf).

The information of genetic species' diversity of blue swimming crab is essential for understanding whether this genetic variation is a factor that could help determine the variation of crab larvae growth rate (Klibunga et al. 2007). The crab from different locations might different trait, differ in the quality and performance due to the environmental factor. In the meantime, crab farmers regard the blue swimming crab as a single stock, which is $P$. pelagicus. However, there are four species of Portunus, each of which has different life requirements. Consequently, they require different management in reproductive aspects (Klibunga et al. 2010; Sienes et al. 2014). An earlier study conducted by Sienes et al. (2014) using the mitochondrial COI gene region showed that $P$. pelagicus from the Philippines consists of two species, which is a clade I, assuming it as a sibling of $P$. segnis.

In contrast, clade 2 is a cryptic species (species is a morphologically that is similar but genetically is different). Previously, Lai et al. (2010) had used the same method to combine morphometric analysis, finding that the genetic diversity of $P$. pelagicus from geographically different locations is high. That crab population consists of four 
species, namely $P$. pelagicus, $P$. armatus, $P$. reticulatus, and $P$. segnis.

Only a few studies have been conducted regarding the genetic diversity of blue swimming crab stock in Indonesia (Lai et al. (2010) and Fujaya et al. (2016). Fujaya et al. (2016) showed that blue swimming crab on Makasar Strait consists of three main groups whose genetic constituent is different. However, very few studies relate to the genetic analysis of blue swimming crab from Indonesian waters. The study aimed to determine the genetic diversity of blue swimming crabs from Indonesian waters using phylogenetic analysis. For this purpose, we conducted a sampling of crab from several Indonesian waters, using genetic DNA mitochondrial (mtDNA) on the COI gene region.

\section{MATERIALS AND METHODS}

\section{Sampling location and collection}

Crab samples were collected from Aceh and Semarang (representing Sunda Shelf), Barru (Makassar Strait) and Maumere, Flores (representing Wallace Region), as well as Sorong, Raja Ampat, and Kaimana (representing Sahul Shelf) (Figure 1). Fresh muscle tissue for DNA analysis was collected at the study sites. From each location, 7 - 15 crab samples/population was collected, with the detail number of samples as follow: Aceh $(n=10)$, Semarang $(n=7)$, Barru $(n=10)$, Maumere $(n=10)$, Sorong $(n=13)$, Raja Ampat $(n=10)$ and Kaimana $(n=15)$. Specimens were identified using taxonomic keys in Lai et al. (2010). Besides, $50 \mathrm{mg}$ of fresh crab muscle tissue from each sample was preserved using a $70 \%$ alcohol solution. The collected samples were stored at room temperature before the DNA extraction process.

\section{DNA extraction, PCR and data analysis}

DNA extraction was done using genomic DNA mini kit (Geneaid). Genetic diversity analysis was performed using Cytochrome c Oxidase Subunit I (COI) with COIa (5' AGTATAAGCGTCTGGGTAGTC-3') and COIf (5'CCTGCAGGAGGAGGAGATCC-3') primers referred to Lai et al. (2010). This primer pair amplifi es a COI fragment that corresponds to positions (5' to $3^{\prime}$ ) 681-1294 of the mitochondrial genome.CO1 gene amplification was conducted using PCR with the initial denaturation program at a temperature of $94^{\circ} \mathrm{C}$ for 2 minutes following 30 cycles of $94^{\circ} \mathrm{C}$ for 1 minute, $50^{\circ} \mathrm{C}$ for 1 -minute, and $72^{\circ} \mathrm{C}$ for 1,5 minutes. The PCR amplification product was then separated using electrophoresis of $2 \%$ agarose gel. DNA fragment from agarose gel was documented using Gel Documentation System (Biometra). Finally, the size of DNA fragment was measured using a 100bp Plus DNA Ladder. Electrophoresis product was purified on an agarose bed (1\% agarose gel, $0.75 \mathrm{~g} ; 75 \mathrm{~mL}$ SB Buffer; $4 \mu \mathrm{L}$ Ethidium Bromide) at $100 \mathrm{~V} / 400 \mathrm{amp}$ for $30 \mathrm{~min}$ before carrying out sequencing.

The phylogenetic tree was created using MEGA 7.0 program (Kumar et al. 2016). The DNAsp ver. 5.10 program (Librado and Rozas 2009) was used to determine the difference of haplotype between the blue swimming crab population from our study sites.

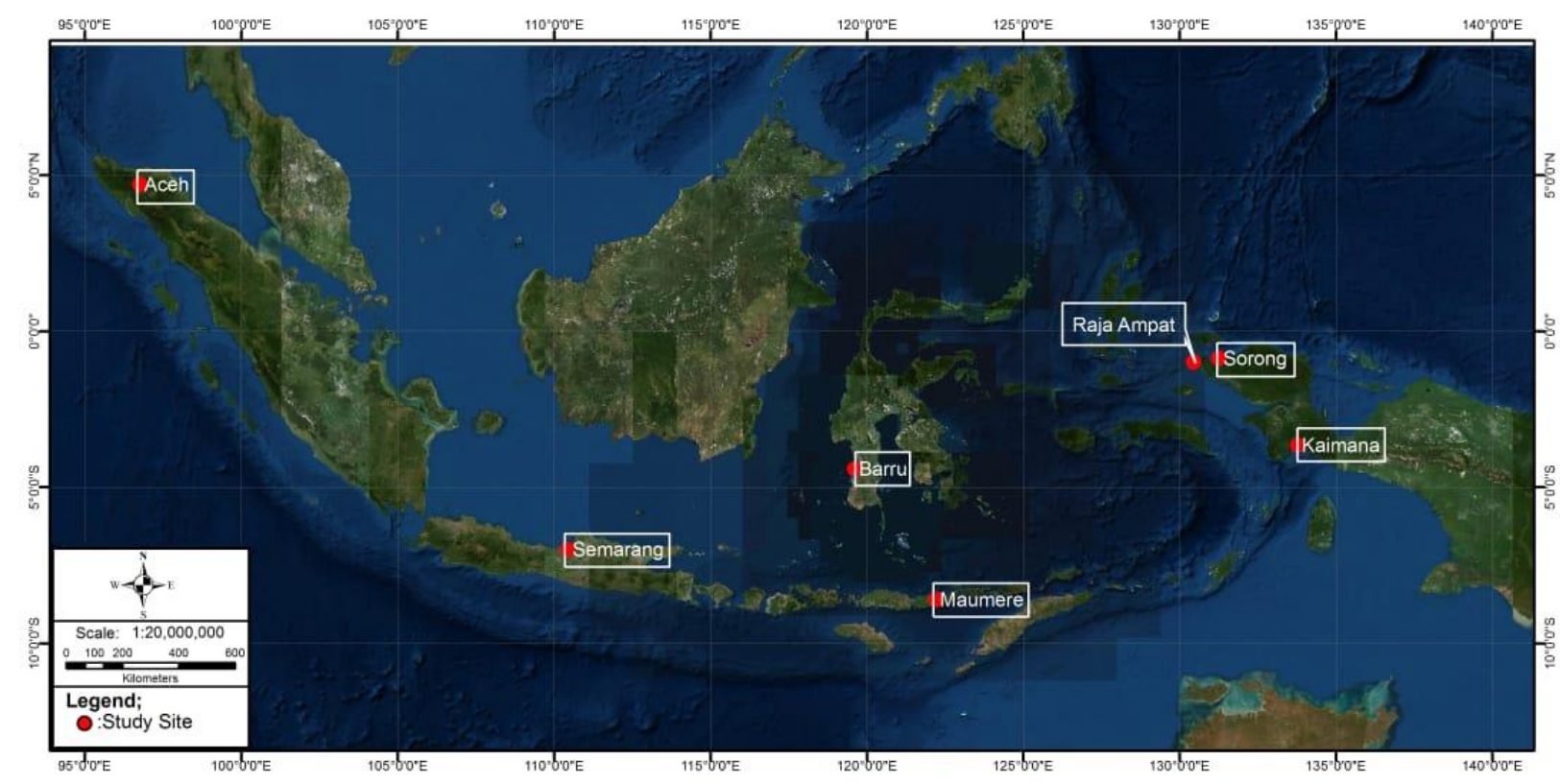

Figure 1. Distribution of sampling site of Portunus pelagicus from Indonesian water 


\section{RESULTS AND DISCUSSION}

Electrophoresis results showed that the COI gene from our samples was 650bp with good quality. The size of after editing sequencing results was $400 \mathrm{bp}$. The DNA analysis result showed that the blue swimming crab population representing Sunda Shelf (Aceh dan Semarang) was into clade I dan II combined with samples from the Wallace Region (Barru and Maumere). Samples from Sahul Shelf (Sorong, Raja Ampat, and Kaimana) was into clade 4; however, one sample from Aceh was into this clade. Gene sequencing of samples from the Sunda Shelf and Wallacea Region exhibited similarity with gene sequencing of Portunus spp from Gene Bank (Figure 2). Gene sequencing of samples from Sahul Shelf has grouped itself and showed only two similarities with two species of $P$. pelagicus and one species of $P$. reticulatus from a gene bank.

Furthermore, our gene sequencing of samples showed a similarity with $P$. pelagicus from Vietnam (accession number: AM410517) and Malaysia (accession number: MK838524). Meanwhile, our gene sequencing of samples was also found to share a similarity with $P$. reticulatus from Pakistan (accession number: KY428868). These results showed a high genetic diversity of $P$. pelagicus in this study.

The evolutionary history was inferred by using the Maximum Likelihood method based on the Tamura-Nei model (1993). The tree with the highest log likelihood (1877.23) is shown in the figure. The percentage of trees in which the associated taxa clustered together is displayed next to the branches. Initial tree (s) for the heuristic search were obtained automatically by applying Neighbor-Join and BioNJ algorithms to a matrix of pairwise distances that were estimated using the Maximum Composite Likelihood (MCL) approach, before selecting the topology with superior log likelihood value. The tree is drawn to scale, with branch lengths being measured in the number of substitutions per site. The analysis involved 92 nucleotide sequences. All positions containing gaps and missing data were eliminated. A total of 158 positions was found in the final dataset. Evolutionary studies were conducted in MEGA 7 (Kumar et al. 2016).

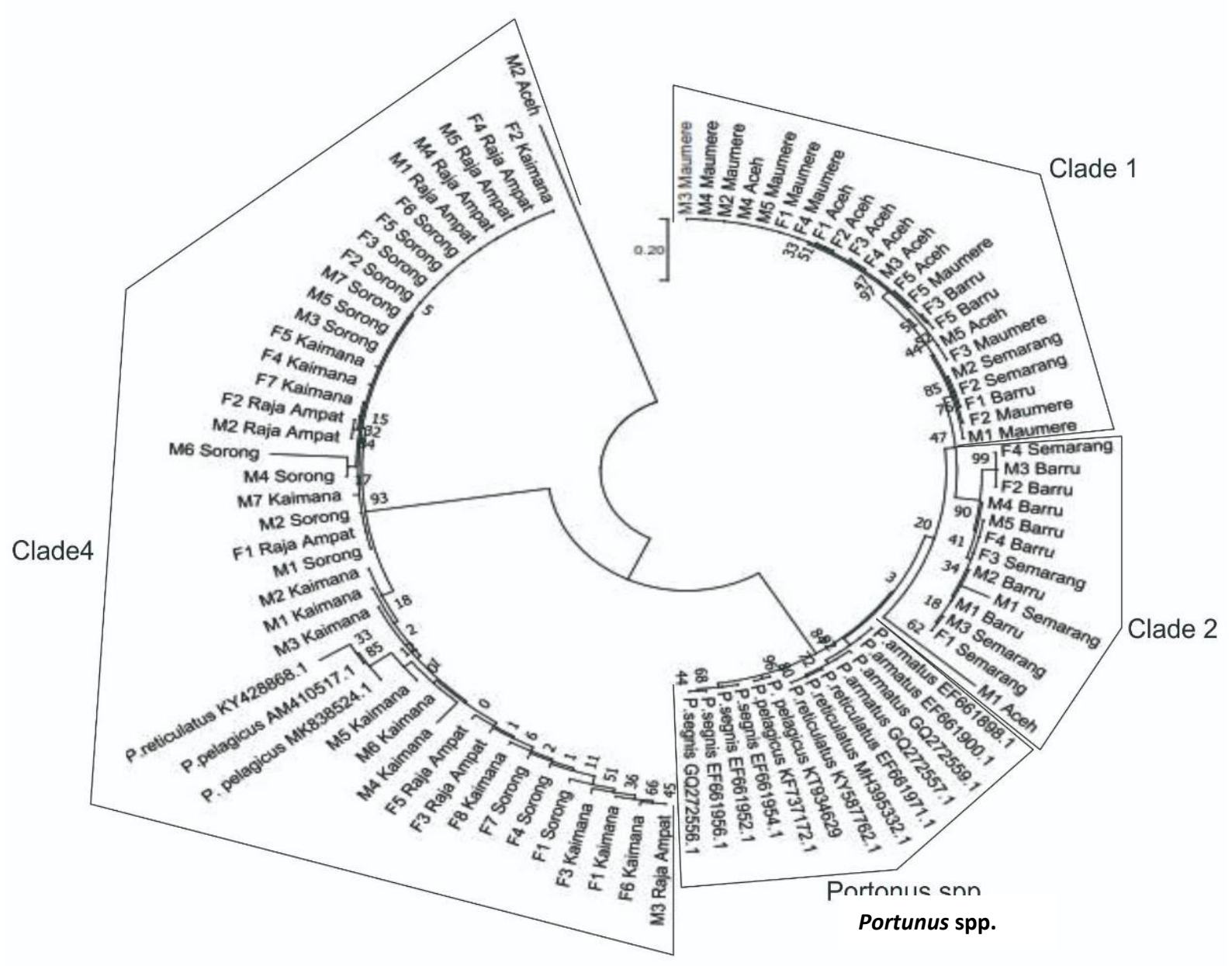

Figure 2. Phylogenetic tree analysis of Portunus pelagicus from Indonesian water by Maximum Likelihood method 
Genetic distance values obtained from distance method in pairwise differences. Almost all samples have a genetic distance value was $<1$, except a sample from Sorong, the genetic distance value was 1 (Tabel 1). This finding indicated that Portunus species from our location have a high genetic variation. Furthermore, the finding for Sorong's sample indicated that there was a totally different species of Portunus and no similarity with other Portunus samples from other locations.

A high of haplotype diversity was shown by the number of haplotypes in this study (accounting for 46) that was spread geographically (Fig.3). Several haplotypes of the same type were found to be scattered at different locations. However, two identical haplotypes ( $\mathrm{H} 4 \mathrm{dan} \mathrm{H} 7)$ from Aceh crab samples were also found at Maumere crab samples. Additionally, four haplotypes (H9, H10, H11 dan H12) of the same time were found at Semarang and Barru crab samples. Meanwhile, crab samples from Sorong, Raja Ampat, and Kaimana were found to have one same haplotype (H21).

Our study found that the number of haplotypes for each crab population from our study sites was similar, except for crab samples from Kaimana, which had the highest number of haplotypes, accounting for 15 haplotypes (Table 2). This finding showed that the diversity of haplotype was a maximum (1). The variety of haplotype and nucleotide in this study were a range of $0.6-1$ and $0.038-0.102$, respectively. Table 3 summarizes the population parameter analyzed using DNAsp version 6 software.

\section{Discussion}

The phylogenetic tree with the Maximum Likelihood method produced four clades. From this phylogenetic tree, Clade I and II showed a combining genetic of $P$. pelagicus sensu stricto (Original species of $P$. pelagicus) from the Sunda Shelf and Wallacea region. Clade II was only found to be dominated by $P$. pelagicus from Semarang and Barru. Clade III was genetic of Portunus spp from gene bank, whereas Clade IV was genetic of $P$. pelagicus from Sahul shelf. However, we only found one male crab from Aceh that belonged to Clade 4. Furthermore, we also found that Clade IV had a similarity of $P$. pelagicus from Malaysia (MK838524) and Vietnam (AM410517). According to our findings, there was a combining genetic of $P$. pelagicus from the Sunda Shelf and Wallacea Region. We assumed that the combined genetic of this $P$. pelagicus is attributed to the current waters of those areas that were also affected by the monsoon season. When west monsoon occurs, water flows from the Pacific Ocean to the Indian Ocean through Indonesia and vice versa for east monsoon.

Table 1. The number of base substitutions per site from averaging over all sequence pairs between populations are shown in distance method of pairwise difference

\begin{tabular}{lllllll}
\hline \multicolumn{1}{c}{ Site } & \multicolumn{1}{c}{ Aceh Semarang Barru Maumere Sorong Raja Ampat } \\
\hline Semarang & 0.819 & & & & & \\
Barru & 0.759 & 0.844 & & & & \\
Maumere & 0.861 & 0.946 & 0.890 & & & \\
Sorong & 1.000 & 1.000 & 1.000 & 1.000 & & \\
Raja Ampat & 0.829 & 0.923 & 0.862 & 0.956 & 1.000 & \\
Kaimana & 0.816 & 0.912 & 0.847 & 0.943 & 1.000 & 0.909 \\
\hline
\end{tabular}

Table 3. Population parameters. Note: number of samples (n), number of haplotypes $(\mathrm{Nh})$, number of the polymorphic site $(\mathrm{Np})$, haplotype diversity (h), and nucleotide diversity $(\pi)$ among the population.

\begin{tabular}{lccccc}
\hline Population & $\mathbf{N}$ & $\mathbf{N h}$ & $\mathbf{N p}$ & $\mathbf{h}$ & $\boldsymbol{\Pi}$ \\
\hline Aceh & 10 & 7 & 57 & 0.911 & 0.1029 \\
Semarang & 7 & 5 & 35 & 0.904 & 0.0785 \\
Barru & 10 & 8 & 34 & 0.955 & 0.0703 \\
Maumere & 10 & 5 & 9 & 0,667 & 0.0138 \\
Sorong & 13 & 8 & 54 & 0.807 & 0.0679 \\
Raja Ampat & 10 & 6 & 24 & 0.844 & 0.0385 \\
Kaimana & 15 & 15 & 39 & 1.000 & 0.0671 \\
\hline
\end{tabular}

Table 2. Haplotype number for each crab population

\begin{tabular}{|c|c|c|c|c|}
\hline Site & Sex & $\begin{array}{l}\text { Number of } \\
\text { haplotypes }\end{array}$ & Haplotype type & Share haplotype \\
\hline \multirow[t]{2}{*}{ Aceh } & Male & 5 & $\mathrm{H} 1, \mathrm{H} 2, \mathrm{H} 3, \mathrm{H} 4, \mathrm{H} 5$ & H4, H7 (Maumere) \\
\hline & Female & 3 & $\mathrm{H} 4, \mathrm{H} 6, \mathrm{H} 7$ & \\
\hline \multirow[t]{2}{*}{ Semarang } & Male & 3 & $\mathrm{H} 8, \mathrm{H} 9, \mathrm{H} 10$ & H9, H10, H11 (Barru) \\
\hline & Female & 4 & H9, H10, H11, H12 & \\
\hline \multirow[t]{2}{*}{ Barru } & Male & 4 & $\mathrm{H} 10, \mathrm{H} 11, \mathrm{H} 13, \mathrm{H} 14$ & H9, H10, H11 (Semarang) \\
\hline & Female & 5 & $\mathrm{H} 9, \mathrm{H} 11, \mathrm{H} 12, \mathrm{H} 15, \mathrm{H} 16$ & \\
\hline \multirow[t]{2}{*}{ Maumere } & Male & 2 & $\mathrm{H} 4, \mathrm{H} 17$ & H4, H7 (Aceh) \\
\hline & Female & 4 & $\mathrm{H} 4, \mathrm{H} 7, \mathrm{H} 18, \mathrm{H} 19$ & \\
\hline \multirow{2}{*}{ Sorong } & Male & 4 & $\mathrm{H} 20, \mathrm{H} 21, \mathrm{H} 22, \mathrm{H} 23$ & H21 (Raja Ampat, Kaimana) \\
\hline & Female & 5 & $\mathrm{H} 21, \mathrm{H} 24, \mathrm{H} 25, \mathrm{H} 26, \mathrm{H} 27$ & \\
\hline \multirow[t]{2}{*}{ Raja Ampat } & Male & 3 & $\mathrm{H} 21, \mathrm{H} 28, \mathrm{H} 29$ & H21 (Sorong, Kaimana) \\
\hline & Female & 5 & $\mathrm{H} 21, \mathrm{H} 28, \mathrm{H} 30, \mathrm{H} 31, \mathrm{H} 32$ & \\
\hline \multirow[t]{2}{*}{ Kaimana } & Male & 7 & H33, H34, H35, H36, H37, H38, H39 & H21 (Sorong, Raja Ampat) \\
\hline & Female & 8 & $\mathrm{H} 21, \mathrm{H} 40, \mathrm{H} 41, \mathrm{H} 42, \mathrm{H} 43, \mathrm{H} 44, \mathrm{H} 45, \mathrm{H} 46$ & \\
\hline
\end{tabular}




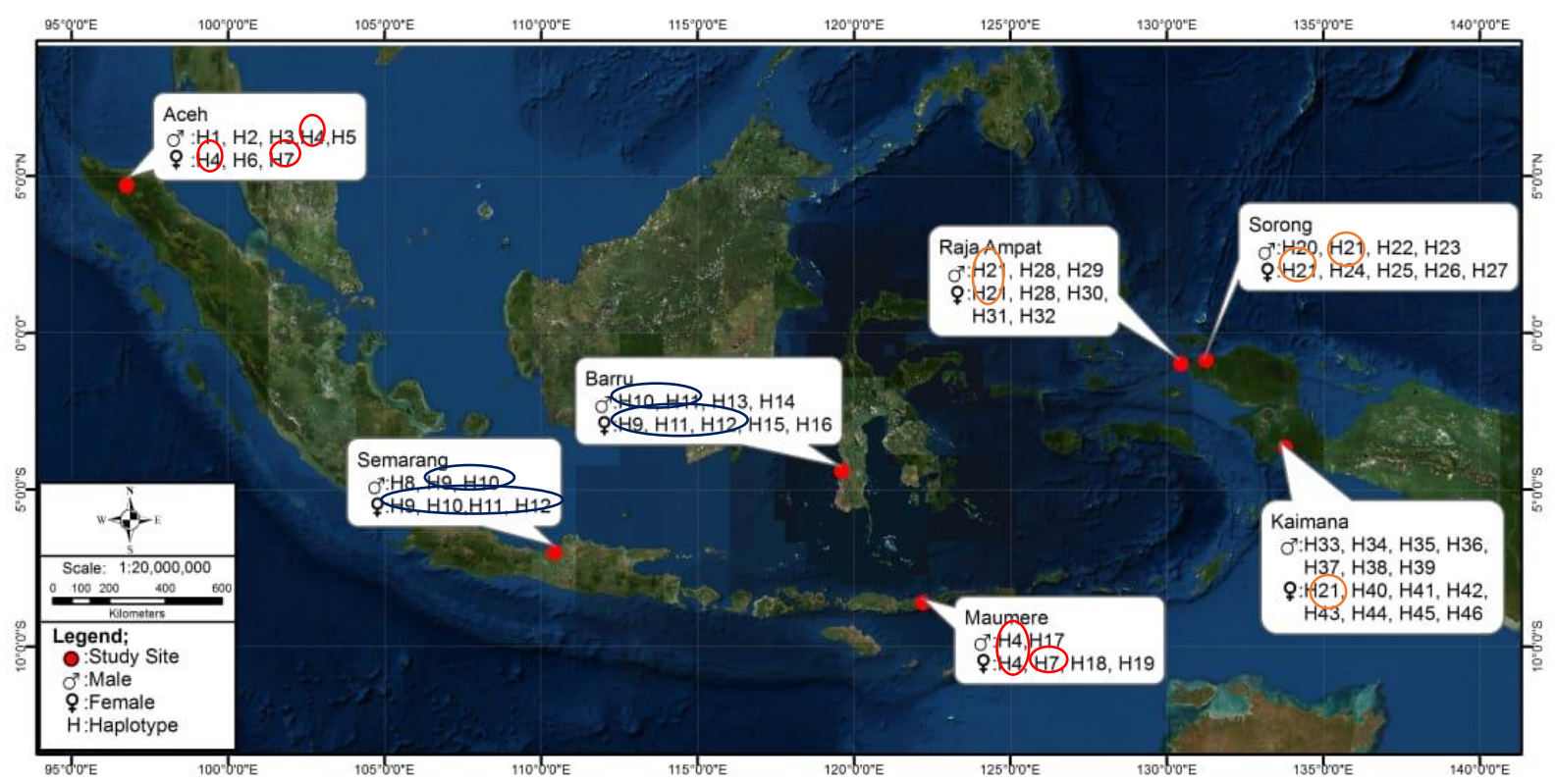

Figure 3. Map of Haplotype distribution of blue swimming crab in the study sites. Note: red, blue, and orange circle showed the same haplotypes in different locations

Those monsoon seasons are known to cause the distribution and mixing of crab larvae into those areas (Daruwedho et al. 2016). Our finding is supported by a previous study conducted by Klinbunga et al. (2007), who found that the larvae stage of $P$. pelagicus is a planktonic organism that had a high dispersal potential and made it possible for the gene to flow extensively between conspecific samples. This larvae dispersal and gene flow among species could be covered for a large geographical area (Klinbunga et al. 2007). Individual mature crabs were also found to contribute to the dispersal of the gene among the population through the mating and spawning process. When female crabs engage in spawning, they tend to migrate from Estuary to the ocean. Generally, this migration is done before their gonad matures completely (Kamrani et al. 2010).

According to this study results, there was one male crab from Aceh that belonged to Clade IV (Sahul shelf Clade population). We assumed that there was an expanded population of $P$. pelagicus from Aceh. This finding was in line with that of a previous study by (McMillen-Jackson and Bert 2004), who explained that the spontaneous expansion of population could affect the genetic diversity of species, in particular between different haplotypes whose existence is more attributed to mutation than those of genetic drift. As a consequence of this phenomenon, several resultant haplotypes could be close to each other, and several original members of the small population will have a high frequency. This haplotype will play an essential role in the genetic change due to an alteration in the environment. This genetic change will also affect the capability of species in terms of survival and reproduction (Sharif et al. 2016).
Our study found that there was not genetic speciation of $P$. pelagicus from the Sunda Shelf and Wallacea Region (Clade I and Clade II), even though they belonged to a different environmental condition. This finding indicated a convergence of their physical characteristics. Supported our results, Bickford et al. (2006) explained that the extreme ecological health led to morphological changes in species caused by the natural selection process. Species that had experienced a strong selection on behavioral and physiological characters for adaptation to a specific condition usually did not show the change in phenotype characters. Meanwhile, the species who could adapt to the extreme environmental situation and pass the strong selection converged their physical characteristics and speciate through habitat fragmentation, subsequence drift as well as other mechanisms relating to cryptic species.

Our results showed that $P$. pelagicus from Sahul Shelf had a genetic similarity with $P$. pelagicus and $P$. reticulatus in the gene bank; however, this male crab had a morphological similarity with $P$. armatus (Hidayani et al. 2018). This finding indicated that there was a formation of cryptic species in our study's crab population. Bickford et al. (2006) and von der Heyden et al. (2014) explained that cryptic species is a sibling species that came from the same ancestors whose existence is attributed to the overlapping phenotype. Furthermore, they also revealed that the formation of cryptic species was possibly caused by hybridization.

Genetic analysis result showed that there was a phenotype character convergence between $P$. pelagicus and $P$. armatus or $P$. reticulatus and $P$. armatus. This result was indicative of hybridization between $P$. pelagicus $/ P$. reticulatus and $P$. armatus and supported the finding of a previous study (Bryars and Adams (1999). They reported a 
hybridization of crab between P. armatus dan P. pelagicus in Australia. Correspondingly, Klinbunga et al. (2007) also said that the hybridization occurred for Portunid in Thailand, whereas there was hybridization between $P$. pelagicus and $P$. reticulatus at Bay Andaman Sea. Lai et al. (2010) meanwhile found that there was a hybridization phenomenon between $P$. pelagicus and Phrynocephalus reticulatus at the Bengala Bay.

This study found that it is difficult to differentiate between the phenotype characteristic of $P$. reticulatus and $P$. armatus as well as $P$. pelagicus and $P$. segnis. Based on the nucleotide diversity (Table 2), a high nucleotide value of our crab samples was found in several locations, except a sample from Maumere and Raja Ampat. This finding was indicative of high genetic similarity. Lai et al. (2010) explained that there was a difficulty in carrying out a genetic differentiation between $P$. reticulatus and $P$. armatus as well as $P$. pelagicus and $P$. segnis due to only $2 \%$ and $3.14 \%$ of their genetic distance, respectively. According to them, species that have a close genetic distance could share their haplotype through a hybridization process.

In conclusion, the genetic diversity of $P$. pelagicus from Indonesian waters was found to be high. Three genetic clades of our crab were discovered, namely Clade I, Clade II, and Clade IV. There was no genetic speciation of crab samples from the Sunda Shelf and Wallacea Region, except for the samples from Sahul Shelf. Besides, hybridization occurred between species and created a cryptic species.

\section{ACKNOWLEDGEMENTS}

We would like to express our gratitude to Hasanuddin University, which funded this research through the BOPTN Research Project Scheme 2017. We also thank Prof. Marc Kochiuz, who helped us in sequencing several samples in Brussels.

\section{REFERENCES}

Bickford D, Lohman DJ, Sodhi NS, Ng PKL, Meier R, Winker K, Ingram KK, Das I. 2006. Cryptic species as a window on diversity and conservation. Trends Ecol Evol 22 (3): 148-155.

Bryars SR, Adams M. 1999. An allozyme study of the blue swimmer crab, Portunus pelagicus (Crustacea: Portunidae), in Australia: Stock delineation southern Australia and evidence for a cryptic species in northern waters. Mar Freshw Res 50 (1): 15-26.

Daruwedho H, Sasmito B, Amarrohman FJ. 2016. Analisis pola arus laut permukaan perairan Indonesia dengan menggunakan Satelit Altimetri Jason-2 Tahun 2010-2014. Jurnal Geodesi Undip 5 (2): 147-158. [Indonesian]

FAO Fisheries and Aquaculture Department. 2014. A species fact sheets Portunus pelagicus (Linnaeus, 1758). FAO, Rome. www. fao.org.

Fujaya Y, Asphama AI, Hidayani AA, Parenrengi A, Tenriulo A. 2016 High genetic variation of Portunus pelagicus from Makassar Straits revealed by RAPD markers and mitochondrial $16 \mathrm{~S}$ rRNA sequences. Afr J Biotechnol 15 (7): 180-190.
Garcia de Leaniz C, Fleming IA, Einum S, Verspoor E, Jordan WC, Consuegra S, Aubin-Horth N, Lajus D, Letcher BH, Youngson AF, Webb JH, Vøllestad LA, Villanueva B, Ferguson A, Quinn TP. 2007. A critical review of adaptive genetic variation in Atlantic salmon: Implications for conservation. Biol Rev 82 (2): 173-211.

von der Heyden S, Beger M, Toonen RJ, van Herwerden L, Juinio-Meñez MA, Ravago-Gotanco R, Fauvelot C, Bernardi G. 2014. The application of genetics to marine management and conservation: Examples from the Indo-Pacific. Bull Mar Sci 90 (1): 123-158.

Hidayani AA, Trijuno DD, Fujaya Y, Alimuddin, Umar MT. 2018. The morphology and morphometric characteristics of the male swimming crab (Portunus pelagicus) from the east Sahul Shelf, Indonesia. AACL Bioflux 11 (6): 1724-1736.

Kamrani E, Sabili AN, Yahyavi M. 2010. Stock Assessment and Reproductive Biology of the Blue Swimming Crab, Portunus pelagicus in Bandar Abbas Coastal Waters, Northern Persian Gulf. J Perian Gulf 1 (2): 11-22.

Klinbunga S, Khetpu K, Khamnamtong B, Menasveta P. 2007. Genetic heterogeneity of the blue swimming crab (Portunus pelagicus) in Thailand determined by AFLP analysis. Biochem Genet 45: 725-736.

Klibunga S, Yuvanatemiya V, Wongphayak S, Khetpu K, Menasveta P, Khamnamtong B. 2010. Genetic population differentiation of the blue swimming crab Portunus pelagicus (Portunidae) in Thai waters revealed by RAPD analysis. Genet Mol Res 9 (3): 1615-1624.

Kumar S, Stecher G, Tamura K (2016) MEGA7: molecular evolutionary genetics analysis version 7.0 for bigger datasets. Mol Biol Evol 33: 1870-1874

Kunsook C, Gajaseni N, Paphavasit N. 2014. A stock assessment of the blue swimming crab Portunus pelagicus (Linnaeus, 1758) for sustainable management in Kung Krabaen Bay, Gulf of Thailand. Trop Life Sci Res 25 (1): 41-59.

Lai JCY, Ng PKL, Davie PJF. 2010. A revision of the Portunus pelagicus (Linnaeus, 1758) species complex (Crustacea: Brachyura: Portunidae), with the recognition of four species. Raffles Bull Zool 58 (2): 199-237.

Librado P, Rozas J. 2009. DnaSP v5: A software for comprehensive analysis of DNA polymorphism data bioinformatics. Bioinformatics 25: 1451-1452. DOI: 10.1093/bioinformatics/btp187.

McMillen-Jackson AL, Bert TM. 2004. Mitochondrial DNA variation and population genetic structure of the blue crab Callinectes sapidus in the eastern United States. Mar Biol 145: 769-777.

Mehanna SF, Khvorov S, Al-Sinawy M, Al-Nadabi YS, Al-Mosharafi M. 2013. Stock assessment of the blue swimmer crab Portunus pelagicus (Linnaeus, 1766) from the Oman Coastal Waters. Intl J Fish Aquat Sci 2 (1): 1-8.

Sawitri R, Takadjandji M. 2014. Keragaman genetik dan situs polimorfik Trenggiling (Manis javanica Desmarest, 1822) di Penangkaran. Jurnal Penelitian Hutan dan Konservasi Alam 11 (1): 1-11. [Indonesian]

Sawusdee A, Songrak A. 2009. Population dynamics and stock assessment of blue swimming crab (Portunus pelagicus Linnaeus, 1758) in the Coastal Area of Trang Province, Thailand. Walailak J Sci Tech 6 (2): 189-202.

Sharif NAM, Kahar NAS, Rodrigues K, Ransangan J, Kian AYS. 2016. Genetic diversity of mud crabs, Scylla transquebarica in Sabah, Malaysia based on cytochrome C oxidase (COI) gene sequence. Songklanakarin J Sci Technol 38 (4): 365-372.

Sienes PMQ, Willette DA, Romena LR, Alvior CG, Estacion JS. 2014. Genetic diversity and the discovery of a putatic cryptic species with in a valued crab fishery, Portunus pelagicus (Linnaeus 1758), in the Philippines. Philippines Sci Lett 7 (2): 317-323.

Svane I, Hooper G. 2004. Blue Swimmer Crab (Portunus pelagicus) Fishery, Fishery Assessment Report to PIRSA for the Blue Crab Fishery Management Committee. South Australian Research and Development Institute (Aquatic Sciences), Adelaide RD03/02742.

Tamura K, Nei M. 1993. Estimation of the number of nucleotide substitutions in the control region of mitochondrial DNA in humans and chimpanzees. Mol Biol Evol 10: 512-526. 